\title{
PEMANFAATAN SISTEM INFORMASI APLIKASI ONLINE PUBLIC ACCESS CATALOGUE (OPAC) PADA PERPUSTAKAAN IAIN BATUSANGKAR
}

\author{
Armizawati \\ Program Studi Manajemen Pendidikan Islam, \\ Jurusan Tarbiyah IAIN Batusangkar \\ e-mail : Armizawati79@gmail.com
}

\begin{abstract}
In this qualitative case study, we examined benefit Online Public Acsses Catalogue (OPAC) in IAIN Library. This research focus to student that use Online Public Access Catalogue (OPAC). This research using Miles \& Hubberman model (Reduction data, show data and conclusion). Data were collected purposive sampling through observation and interview. The findings, showed that Online Public Acsses Catalogue $(O P A C)$ give benefit,effective and efisien use to find all book fast.
\end{abstract}

Keyword : Benefit OPAC,Student IAIN Batusangkar

\begin{abstract}
Abstrak: Dalam studi kasus kualitatif ini, kami menguji manfaat Online Public Acsses Catalog (OPAC) di Perpustakaan IAIN. Fokus penelitian ini kepada siswa yang menggunakan Katalog Akses Publik Online (OPAC). Penelitian ini menggunakan model Miles \& Hubberman (Reduksi data, tunjukkan data dan kesimpulan). Data dikumpulkan secara purposive sampling melalui observasi dan wawancara. Temuan, menunjukkan bahwa Online Public Acsses Catalog (OPAC) memberikan manfaat, efektif dan efisien untuk menemukan semua buku dengan cepat.
\end{abstract}

Kata kunci: Manfaat OPAC, Mahasiswa IAIN Batusangkar

\section{PENDAHULUAN}

Penelitian ini berawal dari temuan dari temuan empiris bahwa " perpustakaan hendaklah menggunakan teknologi canggih untuk mempercepat akses informasi" (hasil wawancara dengan Arif). Hal tersebut menjadikan perpustakaan adalah inti dari setiap program pendidikan dan pengajaran atau dalam bahasa asingnya "the heart of educational (Soedibyo:1987). program" jantungnya pendidikan, perpustakaan Perguruan Tinggi berfungsi sebagai media pembelajaran yang berperan dalam menyediakan koleksi buku, audio, visual juga menyediakan koleksi jurnal ilmiah yang berperan vital dalam menyokong kegiatan penelitaian (Utami:2013). Munurut Darmono (2001) Pentingnya perpustakaan sekolah dapat dilihat dalam Undang-Undang No. 2 Tahun 1989 Pasal 35 tentang Sistem Pendidikan Nasional, yaitu dinyatakan bahwa setiap satuan pendidikan jalur pendidikan sekolah yang diselenggarakan oleh pemerintah maupun masyarakat 
harus menyediakan sumber belajar. Salah satu sumber belajar yang amat penting, tetapi bukan satu-satunya adalah perpustakaan (Fahmi: 2010).

\section{Perpustakaan dalam} perguruan tinggi merupakan suatu bagian yang sangat penting dalam penyelenggaraan, seperti yang tercantum dalam undang-undang Republik Indonesia No.43 Tahun 2007 pasal 24 ayat 1 tentang keberadaan perpustakaan di perguruan tinggi yang berbunyi “" Setiap Perguruan Tinggi menyelenggarakan Perpustakaan yang memenuhi Standar Nasional Perpustakaan dengan memperhatikan standar nasional pendidikan". Untuk memenuhi Standar tersebut pustaka sebagai sumber informasi atau gudang ilmu dituntut untuk memberikan layanan informasi yang baik, efektif dan efiisien guna membantu mendapatkan informasi sesuai dengan sumber pendukung yang akan dicari. Istilah sumber pendukung disini adalah jumlah koleksi buku yang mempunyai ratusan jumlah dan harus menemukannya sesuai dengan sumber yang dinginkan dengan cara efektif dan efisien. Hal ini tentu saja akan sangat menyulitkan jika perpustaan masih menggunakan sistem tradisional dalam pengkataloan koleksi sehingga perpustakaan dituntuk untuk memberikan perkembangan sistem baru yang lebih otomatis.

Beranjak dari UU RI No 43 tersebut, tim peneliti ingin merancang penelusuran jurnal otomatis yang sering disebut dengan OPAC yaitu online public access catalogue (Arianto: 2006) berbasis subject indexing lengkap dengan tampilan abstraknya. Menurut Martono (1991), katalog adalah alat bantu untuk mempermudah penelusuran bahan pustaka. Perancangan katalog online/terpasang (Santoso: 2004) ini dikembangkan merujuk pada karakteristik permasalahan dalam penelusuran jurnal dengan tujuan agar pemustaka mendapatkan layanan yang memuaskan (Utami:2013)

Sebelum membahas desain dan standar perpustakaan perlu diketahui beberapa istilah yang berkaitan dengan perkembangan Perpustakaan di instansi pemerintah adalah sebagai berikut : (1) Perpustakaan Kuno: perpustakaan zaman dulu yang belum memakai katalog; (2) Perpustakaan tradisional : kumpulan koleksi buku dan tidak ada otomasi katalog;

Perpustakaan Semi Modern : adanya katalogisasi, pengindeksan dan klasifikasi secara manual dan automasi (disebut hybrid library); (4) Perpustakaan Modern : semuanya full automation atau menggunakan computer dan jaringan komputer sebagai alat bantu layanan perpustakaan dan pengelolaannya (penekanannya pada proses dan sarananya yang elektronik/digital), tetapi koleksinya sebagian besar dalam bentuk tercetak, sifatnya relatif tergantung dari perkembangan zaman dan teknologi; (5) Perpustakaan Digital: secara fisik mirip dengan perpustakan modern, tetapi penekanannya pada koleksinya, dimana sebagian besar sudah dapat diakses dalam bentuk 
file digital ; dan (6) Perpustakaan Maya/Virtual : seluruh koleksinya dalam bentuk digital (e-document) dan diakses melalui internet, intranet (dalam suatu jaringan), serta terkadang tidak ada bentuk fisik perpustakaannya (Susanto:2010)

Dalam hal ini perpustakaan pada IAIN Batusangkar termasuk salah satu perpustakaan yang Modren yang telah menggunakan sistem outomasi komputer dalam memberikan layanan perpustakaan dilihat hasil observasi awal yang menggambarkan sistem outomasi data statistik pengunjung telah menggunakan scan barcode data, peminjaman dan pengembalian buku dengan barcode data serta pencarian katalog / koleksi buku yang telah menggunakan sistem OPAC. Sejalan dengan pendapat Qolyubi (2007:405), mengatakan bahwa OPAC merupakan system pengatalongan berbasis computer yang telah memiliki pengaruh besar pada proses pengatalongan sejan tahun 1980-an. OPAC menjadi salah satu sarana atau alat bantu untuk melakukan penelusuran informasi yang ada di perpustakaan (Nadfilah:2000)

Adanya informasi yang baik dalam pelayanan, pengelolaan perpustakaan, maka penanganan terhadap peminjaman, pengembalian, perhitungan denda, pembuatan laporan, pencarian koleksi pustaka menjadi lebih baik, cepat, efektif, jelas terperinci . menurut Hermanto (2007:1) OPAC memiliki keuntungan yaitu penelusuran informasi koleksi dapat dilakukan secara cepat dan tepat. Hasugian
(2004:9) menyatakan bahwa OPAC memiliki beberapa kelebihan di banding menggunakan katalog kartu yaitu sisi penelusuran mencakup interaksi (interaction), OPAC menyediakan membantu pengguna (user assistance) dalam penelusuran koleksi. OPAC memberikan kepuasan pengguna (user satisfaction) karena dirasa penelusuran informsi koleksi menjadi cepat dan mudah. Kemampuan penelusuran (searching capabilities) OPAC yang cepat. Informasi dari OPAC akurat, tampilan (out and display) OPAC menarik. Ketersediaan (availability) di setiap ruangan diperpustakaan serta kemudahan mengakses (access) opac diluar perpustakaan.

Penggunaan aplikasi OPAC seharusnya memberikan kemudahan mahasiswa dalam mencari buku, namun pada kenyataan yang diperoleh dari hasil observasi awal keberadaan OPAC belum tersentuh dan termanfaatkan oleh mahasiswa dalam pencarian buku sumber yang mereka butuhkan. Terlihat dari pengamatan awal waktu pelayanan tanggal 19 oktober 2015 yang telah dibuka hingga pukul 09.00 wib belum ada yang menggunakan aplikasi tersebut dibandingkan dengan jumlah pengunjung perpustakaan yang sudah melebihi 20 orang. Pada hari berikutnya penggunaan OPAC telah mengalami peningkatan sebanyak 30 orang. Namun pada saat tertentu mereka mengantri untuk menggunakan OPAC tersebut karena komputer opac yang terbatas. Hal ini didukung oleh penelitian (Lusi,2010) data menunjukkan bahwa pengguna 
OPAC tahun 2008 sebanyak 352.052 pengguna dan tahun 2009 sebnyak 371.097 pengguna. Namun peningkatan pengguna OPAC tidak diimbangi dengan peningkatan ketersediaan terminal OPAC di perpustakaan Universitas Airlangga.

Kebanyakan mahasiswa langsung menuju rak koleksi buku sumber yang dicari karena komputer OPAC yang disediakan yang terletak di sudut pintu koleksi kurang menjadi perhatian siswa dalam mencari koleksi buku, mahasiswa terlihat mengalami kebingunan saat menggunakan opac dan tidak tahu cara menggunakan opac itu sendiri. Ditinjau dari segi penggunaan Menurut Filia (hasil wawancara 2015)"penggunaan opac itu sendiri dia gunakan jika ia mengalami kebingungan pada saat mencari koleksi buku".Hal ini didukung oleh penelitian (Lusi,2010) yang mengatakan bahawa kurangnya sosialisasi penggunaan OPAC dari pihak pustakawan. Hal ini menjadi perhatian peneliti tentang pemanfaatan komputer OPAC yang belum termanfaatkan dengan maksimal oleh pengunjung perpustakaan. Hal ini juga sejalan dengan hasil penelitian oleh Martina Monisa (2010) yang menunjukkan bahwa penerimaan pengguna OPAC perpustakaan Universitas Airlangga belum optimal. Namun karena adanya ketidaksesuaian antara informasi yang disediakan OPAC dengan kondisi di rak maka ini membuat pengguna jarang menemukan bahan pustaka yang diinginkan di rak koleksi. Kekurangan yang lain yang dirasa pengguna yakni desain OPAC yang kurang menarik serta terkadang sulitnya akses OPAC saat berada diluar perpustakaan". Dari hal tersebut, dapat ditarik permasalahan yang dihadapi pada penelitian ini, yaitu Pemanfaatan Sistem Informasi Aplikasi Online Public Acsses Catalogue (OPAC) pada Perpustakaan IAIN Batusangkar sehingga peneliti membatasi masalah yang diteliti yaitu bagaimanakah permanfatan sistem informasi aplikasi Online Public Acsess Catalogue (OPAC) pada perpustakaan IAIN Batusangkar sudah termanfaatkan oleh mahasiswa dalam mencari koleksi buku dengan semestinya.

\section{METODOLOGI PENELITIAN}

Penelitian ini menggunakan jenis penelitian kualitatif studi kasus atau case study. Case study didefinisikan sebagai pendekatan penelitian yang melakukan eksplorasi suatu fenomena dalam konteksnya dengan menggunakan data dari berbagai sumber (Baxter \& Jack 2008;Yin2009,p.9). Case Study menyiratkan peneliti melakukan analisis secara intensif pada satu unit analisis yang diteliti (Case). Study kasus atau Case Study dalam hal ini bertujuan untuk mengetahui Pemanfaatan Sistem Informasi Aplikasi online public acsses cataloque (Opac) pada Perpustakaan IAIN Batusangkar. Penelitian ini ditekankan oleh peneliti terhadap mahasiswa di IAIN Batusangkar yang menggunakan OPAC namun tidak menutup kemungkinan pengambilan data dilakukan dengan mahasiswa belum pernah menggunakan karena mengingat penelitian ini melihat gambaran 
secara umum tentang pemanfaatan OPAC.

Instrumen penelitian yang digunakan adalah dengan metode wawancara dan observasi atau studi lapangan. Wawancara didefinisikan sebagai diskusi antara dua orang atau lebih dengan tujuan tertentu (Khan \& Cannell 1957). Dengan wawancara peneliti dapat memperoleh banyak data yang berguna bagi penelitiannya(Leedy \& Ormrod 2005; Saunders, Lewis \& Thornhill 2007). Wawancara memungkikan peneliti menggali data yang "kaya" dan multi dimensi mengenai suatu hal dari para partisipan (Myers 2009). Metode wawancara dilakukan untuk menggali informasi dan keterangan serta upaya maupun kendala yang dialami dari pihak pengunjung perpustakaan terkait keefektifan penggunaan sistem yang ada. Menurt Hughes (2005) Metode observasi didefinisikan sebagai pengamatan akan manusia pada "habitatnya"(Sarosa,2012).

Observasi bertujuan untuk melihat keadaan sistem yang sedang berjalan dengan meringkasnya serta menemukan permasalahan yang ada serta kebutuhan sistem yang ada.

Berdasarkan dari teori diatas, sumber data dalam penelitian ini adalah peneliti memilih informan yang telah atau pernah menggunakan sistem aplikasi OAPC karena disini merupakan bagian penting yang butuhkan untuk mendapatkan informasi tentang keefektifan penggunaan OPAC tersebut. Peneliti dalam menentukan informan penelitian yaitu dengan cara purposive sampling. Purposive sampling adalah salah satu jenis pengambilan sampel dalam penelitian kualitatif . Menurut Gay (2000 : 138 ), purposive sampling berarti peneliti memilih sampel berdasarkan nya pengalaman atau pengetahuan dari kelompok untuk menjadi sampel. Ukuran sampel purposive Sampling yang diperlukan sangat bergantung pada sumber, waktu yang tersedia, dan tujuan penelitian (Arifin,2011:167).

Informan penelitian ini adalah mahasiswa yang mengunjungi perpustakaan yang telah atau pernah menggunakan sistem aplikasi OAPC. Infroman dalam penelitain ini adalah 10 orang dari berbagai latar belakang prodi, dan tingkat semester yang berbeda. Teknik pengambilan data dengan menggunakan metode observasi dan wawancara. Peneliti menggunakan telepon genggam atau tape recorder untuk mendapatkan reaksi atau jawaban dari pertanyaan yang diberikan peneliti kepada informan dan sekaligus menjadi bahan atau alat pendukung dalam melakukan penelitian ini. Analisis data yang digunakan dalam penelitian ini adalah Miles \& Hubberman yaitu dengan 3 alur : (1) Reduksi data, (2) Penyajian data dan , (3) Penarikan kesimpulan / verifikasi (Emzir,2011:129).

HASIL PENELITIAN DAN
PEMBAHASANNYA
Pada bagian r ini
menggambarkan hasil tentang
Pemanfaatan Sistem Informasi
Aplikasi Online Public Acsses
Catalogue (Opac) pada Perpustakaan
IAIN Batusangkar. Pengambilan data
dilakukan dengan melakukan




\begin{abstract}
wawancara kepada 10 orang informan yang datang keperpustakaan baik yang pernah menggunakan opac maupun belum. Wawancara dilakukan mulai hari senin 19 Oktober 2015. Pada saat melakukan wawancara peneliti menggunakan wawancara tidak terstruktrur dan bebas, namun memiliki poin penting yang akan ditanyakan.
\end{abstract}

Berdasarkan dari deskripsi data, maka ada beberapa komponen dari Pemanfaatan Sistem Informasi Aplikasi Online Public Acsses Catalogue (Opac) pada Perpustakaan IAIN Batusangkar .Pemanfaatan pertama ( Kualitas Sistem ) mengenai : (1) Kemudahan pengguna, (2) Kecepatan akses, (3) fleksibel menyatakan bahwa informan1,2,3,4,5 (lampiran). Mereka mengatakan menggunakan opac memberikan kemudahan dalam menemukan koleksi terutama buku. hal ini dapat dilihat dari jawaban informan 1 (Ade) tentang “ bagaimana pendapat anda dengan adanya sistem OPAC ini?" yang menyatakan "mempermudah mahasiswa". kemudian untuk melihat keyakinan atau kejujuran informan dalam menjawab peneliti membrikan pertanyaan kedua " apakah anda yakin sistem OPAC dapat membantu mempermudah anda?". Menurut Ade (informan 1) "yakin yakin". Berdasarkan interview tersebut dapat kita ambil kesimpulan kalau ternyata informan 1 memberikan penilaian bahwa ia telah merasakan manfaaat dengan menggukan sistem OPAC ini. Kemudian untuk memberikan gambaran yang lebih jelas lagi tentang pemanfaatan kemudahan penggunaan OPAC ini dapat kita liat melalui jawaban Andri (informan 2) yang menyatakan bahwa "mempermudah kita dalam mencari buku". Kemudian untuk mendukung jawaban yang diberikan Andri (informan 2) dapat kita lihat jawaban dari Mahmuda (informan 5) berdasarkan pertanyaan apa yang ada rasakan dengan menggunakan OPAC, ia menyatakan bahwa "menggunakan OPAC ini kita merasa lebih, lebih terbantu untuk memudahkan kita dalam mencari buku". Hasil data yang diberikan informan menyatakan bahwa sistem OPAC yang terdapat pada Perpustakaan IAIN Batusangkar memiliki kemudahan untuk memperoleh informasi seperti yang dikemukakan oleh Sutardji dan Sri (2006:3) yang mengemukakan bahwa kemudahan memperoleh informasi, yaitu sarana yang diberikan dan disediakan perpustakaan untuk menemukan dan memperoleh informasi (bahan pustaka) yang dibutuhkan pengguna.

Berdasarkan hasil penelitian yang telah dilakukan, menunjukkan bahwa mayoritas besar pengguna merasa sistem OPAC yang terdapat pada Perpustakaan IAIN Batusangkar dapat melakukan penelusuran informasi secara cepat dan singkat sehingga pengguna dapat melakukan efisiensi waktu dan pengguna tidak susah-susah melakukan pencarian buku pada rakrak yang ada. Dengan kecepatan akses yang dimiliki sistem OPAC ini, membuat pengguna merasa nyaman dalam melakukan penelusuran informasi menggunakan 
sistem OPAC ini dan membentuk loyalitas bagi pengguna itu sendiri untuk tetap menggunakan sistem OPAC ini dalam melakukan penelusuran informasi. Akan tetapi, bagi sebagian pengguna mengalami kendala dalam melakukan penelusuran informasi menggunakan sistem OPAC ini, kendala tersebut antara lain terkadang pengguna melakukan kesalahan dalam memasukkan keyword dan adanya terkadang adanya koneksi internet yang lambat, dan adanya ketidaksesuaian informasi yang disajikan sistem OPAC dengan keadaan kondisi buku yang sebenarnya (rak buku) membuat pengguna merasa tidak nyaman dalam menggunakan sistem OPAC ini.

Berdasarkan penelitian yang telah dilakukan maka dapat ditarik suatu simpulan bahwa sistem OPAC yang terdapat pada Perpustakaan IAIN Batusangkar memiliki tingkat kecepatan akses yang baik sejalan dengan pendapat yang dikemukakan oleh Sutardji dan Sri (2006: 3) yang mengemukakan bahwa kecepatan memperoleh informasi, yaitu waktu yang dibutuhkan pengguna untuk menemukan dan memperoleh informasi (bahan pustaka), baik melalui alat bantu penelusuran maupun langsung dari petugas perpustakaan.

Data dari jawaban informan yang telah dilakukan maka dapat ditarik suatu simpulan bahwa sistem OPAC yang terdapat pada Perpustakaan IAIN Batusangkar memiliki tingkat fleksibilitas yang baik dengan adanya kemudahan penelusuran informasi langsung pada sistem OPAC itu sendiri sesuai dengan keyword apapun, judul, nama pengarang, dan subyek. Temuan data ini sependapat dengan yang dikemukakan oleh Kusmayadi (2006:53) yang mengemukakan bahwa salah satu tujuan penyediaan OPAC adalah pengguna dapat mengakses secara langsung ke dalam pangkalan data yang dimiliki perpustakaan.

Kemudian pada pemanfaatan kedua (Intensitas Penggunaan Sistem) mengenai: (1) Intensitas pengguna, (2) Membantu Pekerjaan, menyatakan bahwa informan 1 sampai 10 pernah menggunakan opac dan sebagian besar pengguna menilai sistem OPAC yang terdapat pada perpustakaan IAIN Batusangkar merupakan solusi yang tepat untuk membatu mahasiswa jika mengalami kendala ataupun kesulitan dalam menemukan buku yang dibutuhkannya. Adanya kebutuhan yang terpenuhi menimbulkan kepuasan pengguna terhadap sistem OPAC ini. Hasil ini memiliki kesamaan dengan yang dikemukakan oleh Wilard (1983:41) mengemukakan bahwa pada umumnya, pemakai akan merasa puas jika kebutuhan informasinya terpenuhi. Penilaian yang menyatakan penggunaan OPAC dapat membatu pekerjaan dan intensitas pengguna, peneliti menanyakan " berapa kali anda menggunakan OPAC dan apa yang anda cari dengan menggunakan OPAC?". Menurut Andri (Informan 2) menyatakan bahwa "1 kali dalam sehari” selanjutnya mahmuda 
(informan 5) menyatakan bahwa " menggunakan OPAC sering”

Berdasarkan hasil penelitian yang telah dilakukan, menunjukkan bahwa sebagian besar pengguna sistem OPAC yang terdapat pada Perpustakaan IAIN Batusangkar, Perpustakaan memberikan prioritas awal pada sistem OPAC untuk melakukan penelusuran informasi daripada melakukan penelusuran informasi secara manual, pengguna berusaha menggunakan sistem yang lebih efektif dalam melakukan penelusuran informasi. Sedangkan sebagian pengguna menganggap pencarian buku secara manual pada rak buku yang ada lebih tepat karena pengguna dapat mendapatkan wacana lebih akan informasi yang dibutuhkan. Adanya nilai keefektifan dalam penggunaan sistem OPAC ini berimplikasi pada pemenuhan kebutuhan pengguna yang dapat berakibat kepuasan pengguna. Kepuasan pengguna dapat diwujudkan dengan intensitas dan loyalitas dalam menggunakan media sistem OPAC dalam melakukan penelusuran informasi seperti yang dikemukakan oleh Wiyanto dalam Ulidarma (2005:8) mengemukakan bahwa kepuasan pengguna memberikan manfaat antara lain mendorong pengguna untuk kembali memanfaatkan jasa perpustakaan dan mendorong terciptanya loyalitas pengguna.

Dari hasil penelitian yang telah dilakukan, menunjukkan bahwa sebagian besar pengguna menilai sistem OPAC yang terdapat pada Perpustakaan IAIN Batusangkar merupakan solusi yang tepat untuk membantu pengguna untuk mendapatkan informasi sesuai dengan apa yang dibutuhkan dan diharapkan oleh pengguna. Adanya kebutuhan yang terpenuhi menimbulkan kepuasan bagi pengguna terhadap sistem OPAC ini. Dari hasil penelitian ini memiliki kesamaan dengan yang dikemukakan oleh Wilard mengemukakan bahwa pada umumnya, pemakai akan merasa puas jika kebutuhan informasinya terpenuhi.

\section{Pemanfaatan} ketiga (Kepuasan Pengguna) mengenai: (1) Keefektifan, (2) Efisien. Mereka menyatakan bahwa informan 1 sampai 10 mayoritas pengguna menilai bahwa sistem OPAC yang terdapat pada Perpustakaan IAIN Batusangkar ini dapat memenuhi keinginan dan ekspektasi pengguna, sistem OPAC dianggap merupakan solusi yang tepat dalam melakukan penelusuran informasi yang dibutuhkan pengguna. Pengguna merasa bahwa sistem OPAC ini mewakili harapan pengguna akan suatu sistem informasi yang baik yang memiliki kesepatan, kemudahan, dan tingkat obyektifitas sesuatu dengan apa yang diinginkan oleh pengguna serta sistem OPAC Perpustakaan IAIN Batusangkar sudah Up To Date. Artinya setiap ada koleksi baru sudah bisa kita temukan karena petugas Pustaka telah mengentrikan data buku pada layanan sistem OPAC tersebut.

Dari hasil temuan data wawancara pada informan 1 sampai 10 pada penelitian ini, menunjukkan bahwa mayoritas pengguna menilai 
bahwa sistem OPAC yang terdapat pada Perpustakaan IAIN Batusangkar merupakan suatu sistem yang dapat melakukan penelusuran informasi secara cepat sehingga waktu yang dikeluarkan pengguna untuk mendapatkan informasi yang dibutuhkan tidak terlalu lama dan dapat meringankan aktivitas pengguna. Sejalan dengan jawaban yang dikemukakan dalam wawancara oleh Filia (informan 3) berdasarkan pertanyaan "apa yang anda lakukan dalam mencari koleksi buku di pustaka"? ia menyatakan bahwa" tentu akan lebih efisien dengan menggunakan OPAC dulu baru langsung mencarinya ke lokasinya, dibandingkan langsung kelokasi tanpa mengutak atik OPAC terlebih dulu" hal ini sejalan dengan pernyataan Mahmuda (informan 5) yang juga mengatakan bahwa "kita tidak lagi mencari kesana kemari, mencari rak ini, tempat ini, tempat itu, ga lagi seperti itu ,tetapi dengan membuka OPAC ini kita cukup tulis aa kata dasar dari judul buku, kemudian aa dibuka atau dienter secara detai disitu dijelaskan dimana rak jadi apa nama bukunya kemudian bisa langsung kita temui ke rak tersebut kalo memang buku itu ada disitu secepat mungkin bisa ditemukan".

Asumsi pengguna sependapat dengan yang dikemukakan oleh Lamang (2009) yang mengemukakan bahwa nilai otomasi sistem adalah dalam kemampuannya untuk meningkatkan efisiensi, mengurangi sumber daya yang berlebihan serta yang berhubungan dengan kesalahan-kesalahan yang terjadi.

\section{KESIMPULAN}

Berdasarkan penelitian yang telah dilakukan dan meninjau kembali ke rumusan masalah dapat disimpulkan Pemanfaatan Sistem Informasi Aplikasi Online Public Access Catalogue (OPAC) pada Perpustakaan IAIN Batusangkar beberapa hal yang didapat selama pencarian data di lapangan. Keefektifan dilihat dari penerimaan sistem OPAC yang dilakukan di Perpustakaan IAIN Batusangkar yang menyangkut tentang kualitas sistem (system quality), intensitas penggunaan (intention to use), dan kepuasan pengguna (user satisfaction. Berdasarkan hasil yang diperoleh menunjukkan bahwa mayoritas pengguna menyatakan puas terhadap sistem OPAC yang terdapat pada Perpustakaan IAIN Batusangkar ini membuktikan bahwa penilaian tentang penggunaan OPAC sudah baik. Pengguna beranggapan bahwa sistem OPAC ini merupakan pilihan dan solusi yang tepat bagi pengguna serta memberikan manfaat dalam menelusuri informasi yang dibutuhkan secara efektif dan efisien sesuai dengan harapan pengguna.

\section{DAFTAR KEPUSTAKAAN}

Arifin, Zainal. (2011). Penelitian Pendidikan : Metode dan Paradigma Baru. Bandung : PT. Remaja Rosdakarya.

Edy Susanto, Setyo. (2010). Desain Dan Standar Perpustakaan Digital. "Jurnal Pustakawan Volume 10 No.2 November 2010". 
Emzir. (2011). Metodologi Penelitian Pendidikan Kuantitatif \& Kualitatif, Jakarta : PT RajaGrafindo Persada.

Fahmi,Aisyah. (2010). Skripsi Persepsi Siswa Terhadap Pelayanan Sirkulasi di Perpustakaan Man Wonokromo Yogyakarta. Yogyakarta: UIN Sunan Kalijaga.

Gay, L. R. and Peter Airaisan. 2000. Educational Research. Competencies and for Analysis and Application. New Jersey: Prentice Hall. Inc.

Kusmayadi, Eka dan Andriaty. 2006. Kajian Online Public Access Catalogue (OPAC) dalam Pelayanan Perpustakaan dan Penyebaran Teknologi Pertanian. Jurnal Perpustakaan Pertanian. Bogor : Pusat Perpustakaan dan Penyebaran Teknologi Pertanian. Vol.15, No.2.

Lina. 2007, Pengaruh Perbedaan Individual dan Karakteristik Sistem Informasi pada Penerimaan Penggunaan Teknologi Informasi dalam e-library. "Jurnal Ekonomi dan Bisnis Indonesia, Vol. 22, No. 4, h. 447-465, [online], diakses pada 29 Oktober 2015, tersedia di www.besthomebiznetwork.c om/artikel/1/jurnalekonomi-danbisnis.html"
Monisa,Martina. Skripsi Persepsi Kemudahan Dan Kegunaan Opac perpustakaan Unair (Study Deskriptif Menilai Persepsi Kemudahan Dan Persepsi Kegunaan Opac Oleh Pengguna Di Perpustakaan Universitas Airlangga) Surabaya:FISIP UNAIR.

Mulla \& Chandrashekara. (2009). A study on the effective use of online public access catalogue at the libraries of engineering colleges in Karnataka (India)."International Journal of Library and Information Science Vol. 1(3) pp. 029-042,August, 2009

www.academicjournals.org/ ijlis"

Nadfilah,Fiqrotun, (2010), Skripsi Persepsi Pemustaka Terhadap OPAC (Online Public Acces Catalogue) sebagai sarana penelisiran informasi di perpustakaan SMP Muhammadiyah 2 Yogyakarta, Yogyakarta: SMP Muhammadiyah.

Undang-Undang Republik Indonesia Nomor 2.(1989). Sistem Pendidikan Nasional.(http://www.polsri ac.id/panduan/01.\%20umu $\mathrm{m} / 02 . \% 20$ UndangUndang $\%$ 20Republik\%20Indonesia\% 20Nomor\%202\%20Tahun\% 201989\%20Tanggal\%2027 \%20Maret\%201989\%20Ten tang\%20Sistem $\% 20$ Pendidi 
kan\%20Nasional.pdf;diakse s pada tanggal 29 Oktober 2015 pkl 09.42 WIB).

Undang-Undang Republik Indonesia

Nomor 43.(2007).

Perpustakaan. (

http://perpusnas.go.id/iFile

Download.aspx?ID=Attach ment $\% 5$ CProdukHukum $\% 5$

CUU\%2043\%202007\%20P

ERPUSTAKAAN.pdf;

diakses pada tanggal 29

Oktober 2015 pkl 09.45

WIB).

Utami,

Paramita.(2013).

Pengembangan Program

Opac (Online Public Access

Catalogue) Berbasis Subject

Indexing Untuk

Mempermudah Penelusuran

Koleksi Jurnal di

Perpustakaan Universitas

Pendidikan Ganesha."

Jurnal Sains dan Teknologi

Vol.2 No.1 ISSN 2303-3142

April 2013".

Sarosa, Samiaji. (2012). Penelitian

Kualitatif:Dasar-dasar.

Jakarta : PT. Index. 